\begin{tabular}{|l|c|c|c|r|}
\hline $\begin{array}{l}\text { Cuadernos de Investigación Geográfica } \\
\text { Geographical Research Letters }\end{array}$ & 2018 & N $^{\circ} 44(2)$ & pp. 453-473 & $\begin{array}{r}\text { ISSN 0211-6820 } \\
\text { eISSN 1697-9540 }\end{array}$ \\
\hline
\end{tabular}

DOI: http://doi.org/10.18172/cig.3344

(C) Universidad de La Rioja

\title{
ISOTOPIC HYDROGRAPH SEPARATION IN TWO SMALL MOUNTAIN CATCHMENTS DURING MULTIPLE EVENTS
}

\author{
L. HOLKO ${ }^{1 *}$, S. BIČÁROVÁ ${ }^{2}$, J. HLAVČO ${ }^{1}$, M. DANKO ${ }^{1}$, Z. KOSTKA ${ }^{1}$ \\ ${ }^{1}$ Institute of Hydrology, Slovak Academy of Sciences, Bratislava, Slovakia. \\ ${ }^{2}$ Earth Science Institute, Slovak Academy of Sciences, Bratislava, Slovakia.
}

\begin{abstract}
Two-component isotopic hydrograph separation (IHS) was developed to determine the event- and pre-event components of a single storm event. Its application for several sucessive events requires repeated determination of isotopic signatures of end-members (precipitation, pre-event component) for each event. The existence of several possible alternative signatures results in differences in calculated contributions of event-/pre-event components. This article addresses the question of how big the differences could be in small mountain catchments with different methods for detemining the end member signatures. We analyzed data on isotopic composition of daily/event precipitation at different elevations in two catchments located in the highest part of the Carpathians in July 2014. The isotopic composition of streamflow sampled every 4-6 hours was analyzed as well. Elevational gradients of $\delta^{18} \mathrm{O}$ and $\delta^{2} \mathrm{H}$ in precipitation in the study period were $-0.18 \% 100 \mathrm{~m}^{-1}$ and $-1.1 \% \mathrm{o} 100 \mathrm{~m}^{-1}$, respectively. An elevation gradient in deuterium excess $(0.29 \%$ windward side of the mountains was isotopically lighter than expected for a given rain gauge elevation. Five large rainfall-runoff events occurred in the study period in the meso-scale catchment of the Jalovecky creek (Western Tatra Mountains, area $22.2 \mathrm{~km}^{2}$ ) and in the headwater catchment of the Škaredy creek (High Tatra Mountains, area $1.4 \mathrm{~km}^{2}$ ). Isotopic hydrograph separation was conducted using eight options for the isotopic signatures of event and pre-event water. The isotopic signature of the event water (rainfall) was alternatively represented by data from high or low elevations. Pre-event water was represented either by the streamflow before the event or by the value taken from the statistics of the long-term data on isotopic composition of the stream. Both isotopes $\left({ }^{18} \mathrm{O}\right.$ and $\left.{ }^{2} \mathrm{H}\right)$ were used to calculate event water fractions during peak flows of individual events. Calculated peak flow event water fractions were below 0.2-0.3 for most events. However, the differences in calculated event water fractions for alternative isotopic composition of endmembers were significant even if we did not take into account changes in isotopic composition during individual rainfalls. Coefficients of variation for event water fractions calculated for various options varied during individual events from 0.14 to 0.36. Therefore it is perhaps better to use a range of possible values instead of a single accurate number to interpret the IHS results. Hydrograph separations based on ${ }^{18} \mathrm{O}$ and ${ }^{2} \mathrm{H}$ provided similar results.
\end{abstract}




\section{Separación isotópica del hidrograma de crecida en dos pequeñas cuencas de montaña durante múltiples eventos}

RESUMEN. Se llevó a cabo una separación isotópica del hidrograma en dos componentes con el fin de determinar la proporción de agua de lluvia y de agua preexistente de un evento de crecida. Su aplicación para varios eventos sucesivos requiere la determinación reiterada de las señales isotópicas de los distintos componentes (precipitación, agua preexistente) para cada evento. La existencia de varias señales posibles conlleva diferencias en el cálculo de las contribuciones de los distintos componentes. Este artículo responde a la pregunta de cuánto de grandes podrían ser las diferencias debidas a la aplicación de diferentes métodos para la determinación de las señales de los distintos componentes en una pequeña cuenca de montaña. Se analizó la composición isotópica de la lluvia diaria y a escala de evento a diferentes altitudes en dos cuencas localizadas en los Cárpatos en julio de 2014. La composición isotópica del caudal, muestreado cada 4-6 h, también se analizó. Los gradientes altitudinales de $\delta^{18} \mathrm{O}$ y $\delta^{2} \mathrm{H}$ en la precipitación durante el periodo de estudio fueron respectivamente $0.18 \%$ o $100 \mathrm{~m}^{-1}$ y-1.1\% $100 \mathrm{~m}^{-1}$. También se observó un gradiente altitudinal en el exceso de deuterio $\left(0.29 \%\right.$ 100 $\left.\mathrm{m}^{-1}\right)$. La precipitación en la cara norte de las montañas fue isotópicamente más ligera de lo esperado para una altitud dada. Cinco eventos de gran magnitud fueron registrados durante el periodo de estudio en la cuenca de Jalovecký (Tatras Occidentales, $22.2 \mathrm{~km}^{2}$ de superficie) y la cuenca de cabecera de Škaredý (Altos Tatras, $1.4 \mathrm{~km}^{2}$ de superficie). La separación isotópica del hidrograma en dos componentes se llevó a cabo utilizando ocho opciones para el cálculo de las señales del agua de lluvia y del agua preexistente. La señal isotópica de la lluvia fue representada mediante los datos obtenidos en altitudes altas y bajas. El agua preexistente fue representada mediante el caudal previo a la crecida y mediante un valor estadístico de los datos sobre la composición isotópica del caudal tomados a largo plazo. Ambos isótopos, $\delta^{18} \mathrm{O}$ y $\delta^{2} \mathrm{H}$, fueron utilizados para calcular las fracciones de agua de lluvia durante los picos de crecida de los eventos individuales. Estas fracciones estuvieron por debajo de 0.2-0.3 en la mayoría de los eventos. No obstante, las diferencias en el cálculo de las fracciones de agua de lluvia para diferentes composiciones isotópicas de los distintos componentes fueron significativas, incluso sin tener en cuenta posibles cambios en la composición isotópica durante eventos pluviométricos individuales. El coeficiente de variación para las fracciones de agua de lluvia, calculado para las diferentes opciones, varió entre 0.14 y 0.36. Estos resultados sugieren que a la hora de interpretar los resultados de la separación del hidrograma, seguramente es más adecuado usar un rango de posibles valores en vez de un único valor. La separación del hidrograma mediante ${ }^{18} \mathrm{O}$ and ${ }^{2} \mathrm{H}$ arrojó resultados similares.

Key words: isotopic hydrograph separation, oxygen-18, deuterium, elevational gradients, meso-scale catchment, headwater catchment.

Palabras clave: separación isotópica del hidrograma, oxígeno-18, deuterio, gradiente altitudinal, cuenca a mesoescala, cuenca de cabecera. 
* Corresponding author: L. Holko, Dúbravská cesta 9, 84104 Bratislava, Slovakia. E-mail address: holko@uh.savba.sk

\section{Introduction}

Two-component isotopic hydrograph separation(IHS), which provides contributions of the event- (rainfall or snowmelt) and pre-event components (water stored in the catchment before the event) to the hydrograph, remains an important tool in the arsenal of methods for improving understanding of the hydrological cycle in catchment hydrology. It is based on the application of a simple mixing model well known to chemists. A more widespread application of this technique in hydrology started after the publication of a paper by Pinder and Jones (1969), who used water chemistry as a tracer. Calcium, magnesium, sodium, chloride, sulphate and bicarbonate ion concentrations provided the best results in their study. Isotopes of the atoms forming the water molecule (first radioactive tritium, later stable oxygen and hydrogen) have been used in hydrograph separation since the 1970's (Dinçer et al., 1970; Mook et al., 1974; Herrmann et al., 1978).

Numerous worldwide applications of IHS showed that pre-event water accounted for more than half of the runoff or peak flow associated with rainstorms or snowmelt events (e.g., Genereux and Hooper, 1998; Rodhe, 1998). A comprehensive review and evaluation of IHS was recently done by Klaus and McDonnell (2013). Although hydrologists became more aware of the limitations (e.g., Genereux and Hooper, 1998; Burns, 2002, Oshun et al., 2016) and the technique does not contribute anymore to the development of ideas on runoff formation (Klaus and McDonnell, 2013), it may still be useful in improving the understanding of runoff generation in individual case studies conducted in various climatic and physiographic conditions. High-frequency sampling of rainfall and runoff and simultaneous application of both stable isotopes, i.e. oxygen and hydrogen, denoted as a dual isotope approach, is proposed as a progressive direction in the near future (Klaus and McDonnell, 2013).

IHS was originally developed to determine the event- and pre-event components of a single storm event. Due to analytical constraints, either oxygen or hydrogen isotopes were typically used as tracers. Isotope-ratio mass spectrometers (IRMS), which were traditionally used to measure stable isotopes of oxygen and hydrogen in water samples for IHS, can measure only one isotope at a time. If another isotope were to be analyzed, the equipment had to be reset. Furthermore, additional sample treatment was needed to analyze deuterium, increasing the cost of the analysis. Because the variation of stable isotopes of oxygen and hydrogen in water molecules is correlated, it was also assumed that they would provide redundant information. Recent technological development in laser absorption spectroscopy (LAS) gave access to significantly less expensive equipment, the performance of which equals or exceeds that of most IRMS units (Wassenaar et al., 2013). Also, LAS can be used by non-specialists, does not need sample treatment, and provides simultaneous measurements of oxygen and hydrogen isotopes. Although the variation of stable isotopes of oxygen and hydrogen in water samples is correlated, the use of both isotopes may provide unique information to catchment hydrologists (e.g., 
Lyon et al., 2009). Except for identification of evaporated samples (i.e. the ones which should in most applications not be used in further analyses), the dual isotope approach is especially useful in identifying waters of different origin, e.g. from water reservoirs, local groundwaters or precipitation.

Reduced analytical costs allow collection of a much higher number of samples. It is therefore not difficult anymore to analyze a large number of precipitation and streamflow samples from longer periods that contain several storm events. However, application of IHS for several sucessive events requires repeated determination of isotopic signatures of the end-members (precipitation, pre-event component) for each event. If both isotopes are analyzed, IHS can be conducted with both. If both isotopes are available, there is no reason to exclude one of them just because of the expectation of redundant information; the results from the second isotope can validate those from the first. In many catchments, the spatial variability in isotopic composition of precipitation should be considered as well. Thus, there are several possible alternatives on how to conduct the IHS which result in different calculated contributions of event-/pre-event components. Lyon et al. (2009) showed that the average contribution of event water calculated for individual scenarios during the same event ranged from $24 \%$ to $83 \%$.

The overall objective of our work is to improve the knowledge on runoff generation and runoff response to rainfall events in mountain landscapes using hydrometric and isotopic data. The specific objective of this paper is to examine the differences in calculated event water fractions caused by various approaches to computing the isotopic composition of end-members for multiple events in two mountain catchments of different scales. One of them is a meso-scale catchment which is well monitored because in 1986 it was selected as a representative catchment for research of hydrological processes in the highest part of the Carpathians. The second one is a headwater catchment which had not been studied before the large windthrow which hit the Tatra Mountains in November 2004 (Fleischer et al., 2017). We first describe rainfall-runoff events which occurred in the wet July of 2014 and examine altitudinal gradients in the isotopic composition of precipitation and streams. Then, we compare event water fractions during peak flows calculated for several alternative combinations of end member compositions, which varied with method of calculating pre-event water signal, consideration of spatial variability of the event water, and choice of stable isotope (oxygen, hydrogen).

\section{Study area}

The study was conducted in the Tatra Mountains, northern Slovakia. Slovakia is a mountainous country and a regional "water tower" of central Europe since most of the precipitation falling on its territory runs off. The Slovak mountains are part of the Carpathians, which form the eastward continuation of the Alps and extend from the Slovak-Austrian border in a wide crescent-shape arc some $1450 \mathrm{~km}$ long to near Orşova, Romania (Encyclopaedia Britannica). The Tatra Mountains form the highest mountain range of the Carpathians. They are composed of the Western and Eastern Tatras, and form part of the northern boundary of Slovakia with Poland. 
Isotopic hydrograph separations were carried out in the meso-scale catchment of Jalovecký Creek (area $22.2 \mathrm{~km}^{2}$, mean slope $30^{\circ}$ ) located in the Western Tatra Mountains, and in the headwater catchment of Škaredý Creek (area $1.4 \mathrm{~km}^{2}$, mean slope $28^{\circ}$ ) located on the leeward (southern) slopes of the High Tatra Mountains which form part of the Eastern Tatra Mountains (Fig. 1). Both catchments are in the Tatra National Park, where until recently human activities were restricted only to tourism (wood removal related to windthrows and bark beetle outbreaks has been permitted in the national park in recent years). The distance between the two catchments is about $40 \mathrm{~km}$. The different areas of the two catchments are reflected also in their topographic features. While the Jalovecký Creek catchment is composed of several valleys with small riparian areas developed along the stream network in some parts, the Škaredý Creek catchment simply occupies a depression on a large hillslope (Fig. 1). The mean elevation of the Jalovecký Creek catchment is $1500 \mathrm{~m}$ a.s.1. (820-2178 m a.s.1.). The mean elevation of the Škaredý Creek catchment is 1564 m a.s.l.(1125-2060 m a.s.l.). Bedrock in both catchments is composed of igneous and metamorphic rocks (granodiorite, schist). Quaternary glaciofluvial deposits cover a large area, especially in the Jalovecký Creek catchment. Unconsolidated slope deposits are more important in the Škaredý Creek catchment. Soils in both catchments are shallow and stony. Vegetation in the Jalovecký Creek catchment is represented by spruce-dominated coniferous forest (44\% of catchment area), dwarf pine $(31 \%)$ and alpine meadows and rocks $(25 \%)$. In the Škaredý Creek catchment, forest, dwarf pine and slopes with sparse vegetation cover $65 \%, 26 \%$ and $9 \%$, respectively. Mean annual precipitation, runoff and air temperature at the mean altitude in the Jalovecký Creek catchment (1988-2015) are $1550 \mathrm{~mm}, 1010 \mathrm{~mm}$ and $3.0^{\circ} \mathrm{C}$. Longterm meteorological and hydrological data for the entire Škaredý creek catchment do not exist. Mean annual precipitation and air temperature at the Skalnaté Pleso meteorological station, located near the catchment at altitude $1778 \mathrm{~m}$ a.s.1., in the period 1988-2015, are $1429 \mathrm{~mm}$ and $2.7^{\circ} \mathrm{C}$.

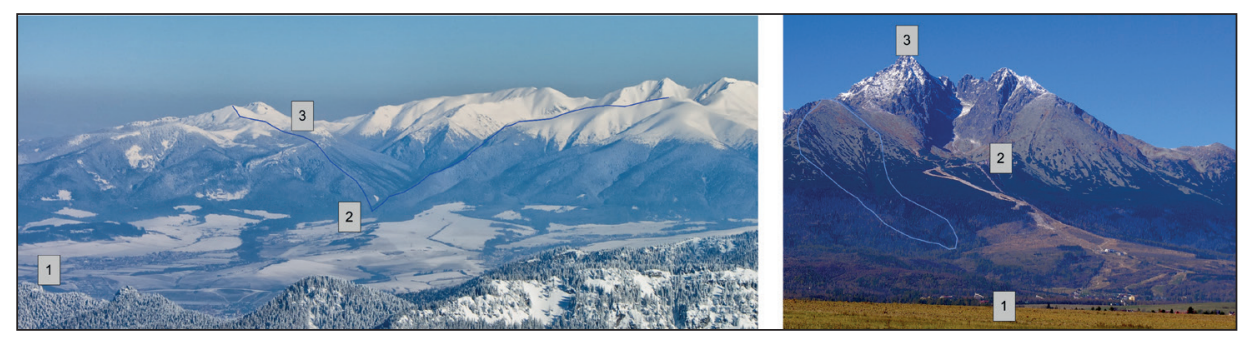

Figure 1. Left: The Jalovecký Creek catchment and rain gauges at $570 \mathrm{~m}$ a.s.l. (1), $750 \mathrm{~m}$ a.s.l. (2) and $1500 \mathrm{~m}$ a.s.l. (3), providing samples for the isotopic analyses; Right: The Škaredy Creek catchment and rain gauges at $810 \mathrm{~m}$ a.s.l.(1), $1778 \mathrm{~m}$ a.s.l.(2) and $2635 \mathrm{~m}$ a.s.l. (3), providing samples for the isotopic analyses; rain gauge at $2635 \mathrm{~m}$ a.s.l.is on the second highest peak of the High Tatra Mountains and the Carpathians. Water divides are shown by blue lines.

Interpretation of the hydrological data in the Jalovecký Creek catchment benefits from the fact that it has been studied as a representative mountain catchment. The broad objective of the research was to improve knowledge on the hydrological cycle of 
mountains. The main research focus is devoted to hydrological balance (e.g. Holko and Kostka, 2010), snow cover (e.g., Holko and Kostka, 2007, 2008; Holko et al., 2009a, 2011a; Parajka et al., 2012; Krajčí et al., 2016) and runoff formation (e.g., Holko et al., 2011b; Hlaváčiková et al., 2015) including the response of catchment runoff to rainfall, climate and land use changes (Kostka and Holko, 2003; Kostka, 2009; Kostka and Holko, 2007; Holko et al., 2009b, 2012a; Bičárová and Holko, 2013). Basic data collected in the catchment are represented by spatially distributed precipitation and stream gauge networks, two meteorological stations and two other sites where soil moisture is measured. Snow depth and water equivalent are measured at different altitudes. Stable isotopes of oxygen and hydrogen have been used as a research tool since the beginning of the 1990's; the first sample was collected in November 1990 (Holko, 1995). Although not all components of the hydrologic cycle are monitored with the same frequency, there are long time series of isotopic composition of precipitation and runoff supplemented by a large database of isotopic composition of snow cover, snowmelt water, soil water and shallow groundwater (Holko et al., 2013). Long-term hydrological research in the Jalovecký Creek catchment has provided climatic and hydrological data series which would otherwise not exist from a relatively inaccessible mountain catchment. This research has improved knowledge on air temperature and precipitation gradients, distribution of snow cover and soil moisture, the hydrological role of stony soils, and runoff formation including response times to rainfall events and hydrograph components. Obtained data also have been used in the assessment of the hydrological response of mountain catchments in the highest part of the Carpathians to climate and land-use changes. The research has enabled participation in international collaborations and preparation of several Ph.D. studies. The Škaredný creek catchment has not been subject to hydrological studies.

\section{Data collection}

This study is based on hydrological data from the period June 25-July 31, 2014. Since it is conducted in the mountains, altitude gradients in precipitation have to be taken into account. In the Jalovecký Creek catchment, we used hourly rainfall data from eleven rain gauges (tipping bucket and weighing bucket) at elevations 820-1900 m a.s.l. The data were used to determine the beginning and end of individual rainfall events. The isotopic composition of precipitation was sampled at elevations $570 \mathrm{~m}$ a.s.l. (below the catchment), $750 \mathrm{~m}$ a.s.l. (near the catchment outlet), $1500 \mathrm{~m}$ a.s.l. (catchment mean altitude) (Fig. 1) and in the forest at $1420 \mathrm{~m}$ a.s.l., close to the site at $1500 \mathrm{~m}$ a.s.l. Fourtytwo precipitation samples were collected during the study period. Standard rain gauges of the Slovak Hydrometeorological Service with an orifice of $500 \mathrm{~cm}^{2}$ were used to collect the rainfall samples. The summer version of the gauge has a funnel (with the same orifice as the collecting gauge) which leads rain water into a sample bottle inside the gauge. The sample bottle was covered to reduce the chance of evaporation. Precipitation samples for isotopic analyses were collected from the gauges manually either daily or after longer rainfall events. Catchment runoff was measured at the outlet ( $820 \mathrm{~m}$ a.s.1.) employing a pressure transducer and discharge rating curve. The Creek was sampled every 4-6 hours at the stream gauge by an automatic sampler. The total number of stream 
samples was 125. A few manual samples were collected during the maintenance of the automatic sampler to validate the samples collected by the sampler. Soil moisture data from several locations and soil depths were available in the catchment. Information on soil moisture variability aids the interpretation of catchment response to rainfall.

Hydrological data from the Škaredý Creek catchment are very limited. Discharge measurements started at the end of October 2007 and finished in August 2014. Basic precipitation data for this study were measured by the tipping bucket gauges near the catchment outlet (elevation $1170 \mathrm{~m}$ a.s.1.) and at $1788 \mathrm{~m}$ a.s.l. Daily samples for isotopic analyses of precipitation were collected in similar fashion to those at Jalovecký Creek catchment. The gauges were located at $810 \mathrm{~m}$ a.s.l. (representing the foothills of the mountain valley below the catchment), $1778 \mathrm{~m}$ a.s.1., $2635 \mathrm{~m}$ a.s.l. (summit position) (Fig. 1) and on the windward (northern) side of the High Tatra Mountains (1100 m a.s.1.). In total, 73 precipitation samples were available for the study. Stream water samples were collected every 4-6 hours by an automatic sampler; the total number of samples was 124.

Isotopic analyses were carried out in the isotopic laboratory of the Institute of Hydrology SAS (Slovak Academy of Sciences) by laser spectroscopy (Picarro 2120i and Picarro 2130i). Each sample was measured three times (in three different vials) with 6-7 injections per vial and the data were processed in accordance with recommendations of Coplen and Wassenaar (2015). Isotope ratios for stable isotopes of oxygen and hydrogen are expressed in $\delta$-values (Vienna Standard Mean Ocean Water, VSMOW). Analytical accuracy was within expected $0.2 \%$ for $\delta^{18} \mathrm{O}$ and $1 \%$ for $\delta^{2} \mathrm{H}$ (Holko, 2015).

\section{Methodology}

We first analyzed the hydrometric data. We compared discharge during the study period with the long-term discharge record at the Jalovecký Creek catchment to characterize the relative wetness of the study period. Then the runoff regime, number of events and their selected characteristics in both catchments were compared.

Second, the isotopic data were evaluated. Boxplots were used to compare the ranges and statistics of the isotopic composition of rainfall at different elevations and the isotopic composition of stream water at the outlets of the catchments. The elevation gradients of $\delta^{18} \mathrm{O}, \delta^{2} \mathrm{H}$ and deuterium excess in precipitation were determined using weighted averages for individual gauges calculated for the entire study period (precipitation amount was used as a weight). Deuterium excess was calculated as $d=\delta^{2} \mathrm{H}-8 \delta^{18} \mathrm{O}$ (Dansgaard, 1964). The value of $d$ is primarily a function of the mean relative humidity of the atmosphere above the ocean water (Merlivat and Jouzel, 1979). It can be used to determine the origin of air masses that brought precipitation, sub-cloud evaporation and continental moisture recycling (Froehlich et al., 2008), and is also used in paleoclimatic studies (Pfahl and Sodemann, 2014). We use deuterium excess to indicate water that underwent evaporation (d was significantly less than 10).

Finally, we conducted IHS for the two study catchments. The results were first analyzed from the point of view of runoff generation in two mountain catchments with different scales. Then, we focused on the differences in IHS peak flow event water 
fractions computed from various combinations of the isotopic composition of the precipitation and pre-event water. A two-component mixing model (Pinder and Jones, 1969) separates stream hydrograph into the event and pre-event components. The general form of the equation is:

$$
F_{\mathrm{e}}=1-\left(\left(\mathrm{C}_{\mathrm{t}}-\mathrm{C}_{\mathrm{e}}\right) /\left(\mathrm{C}_{\mathrm{p}}-\mathrm{C}_{\mathrm{e}}\right)\right)
$$

where $F_{e}$ is the fraction of the event component in the hydrograph, $C_{t}, C_{e}$ and $C_{p}$ are concentrations of the tracer in the stream, in the event component (rainfall or snowmelt) and pre-event component, respectively. The equation is constrained so that $C_{t}$ falls between $C_{p}$ and $C_{e}$ (e.g Klaus and McDonnell, 2013). Delta values $\left(\delta^{18} \mathrm{O}\right.$ or $\left.\delta^{2} \mathrm{H}\right)$ were used for $C_{t}$, $C_{e}$, and $C_{p}$ in IHS, where the isotopes of oxygen and hydrogen are applied as tracers.

The basic assumptions behind isotopic hydrograph separation (Sklash and Farvolden, 1979) as recently formulated by Klaus and McDonnell (2013) are:

(i) The isotopic content of the event and the pre-event water are significantly different.

(ii) The event water maintains a constant isotopic signature in space and time, or any variations can be accounted for.

(iii) The isotopic signature of the pre-event water is constant in space and time, or any variations can be accounted for.

(iv) Contributions from the vadose zone must be negligible, or the isotopic signature of soil water must be similar to that of groundwater.

(v) Surface storage contributes minimally to streamflow.

Several key decisions must be made before IHS is conducted for several successive storm events. They should answer the following questions:

(i) What is the isotopic composition of the pre-event water and does it remain temporally invariant during the event(s)?

(ii) What is the isotopic composition of the event water given the well-documented temporal variability of isotopic composition of precipitation during and between events and its spatial variability within a catchment?

We applied isotopic hydrograph separations for the rainfall-runoff events which occurred in July 2014. We used temporally invariant isotopic composition of the pre-event component during an event. For individual events it is a) equal to the isotopic composition of the stream before the event, i.e. different for individual events; and alternatively b) equal to the third quartile of the long-term data on isotopic composition of streamflow (in the Jalovecký Creek catchment only), i. e. the same for all events. Almost 1200 and 1100 samples for $\delta^{18} \mathrm{O}$ and $\delta^{2} \mathrm{H}$, respectively, were analyzed from the Jalovecký Creek between November 1991 and March 2017. The samples were collected over a range of stream discharge. Daily discharge data series since November 1991 were analyzed to 
determine the discharge below which the low flow with longer duration typically starts. Isotopic composition of stream samples collected at flows below this threshold was then analyzed. The analysis indicated that the third quartile of the isotopic composition of all samples could be used as the value representing the long-term isotopic composition of the stream during low flow conditions.

The spatial variability of isotopic composition of the event water (rainfall) was analyzed based on data from gauges at different elevations. Because we could not maintain a long-term operation of a dense network of sampling stations in the mountain catchments on a daily/event basis, we assumed that the "correct" isotopic composition of precipitation could lie between the vales measured at the catchment's lower and higher elevations. We tested the reasonability of this assumption in our study catchments. The temporal variability within individual rain storms was not monitored by the sampling network. Event water fractions during peak flows of the observed events were calculated with both isotopes.

Based on the above, eight options for combinations of the end members in the IHS were used (Table 1). Precipitation samples collected at $750 \mathrm{~m}$ a.s.l. and $1500 \mathrm{~m}$ a.s.l. represent the lower and higher elevations in the Jalovecký Creek catchment. In the Škaredý Creek catchment, from which no earlier isotopic data were available, only options 3, 4, 7 and 8 were used in the IHS. Low and high elevations in that catchment were represented by samples from rain gauges located at $810 \mathrm{~m}$ a.s.l. and $1778 \mathrm{~m}$ a.s.l.

Table 1. Combinations of the end-members used in the calculation of event water contributions to peak flow during events in the Jalovecký and Škaredý Creek catchments in July 2014.

\begin{tabular}{|c|c|c|c|}
\hline Option & Tracer & $\begin{array}{c}\text { Event water represented by } \\
\text { rainfall samples from }\end{array}$ & $\begin{array}{c}\text { Pre-event water represented by } \\
\text { stream water from }\end{array}$ \\
\hline 1 & $\delta^{18} \mathrm{O}$ & Low elevation & Long-term low flow data \\
\hline 2 & $\delta^{18} \mathrm{O}$ & High elevation & Long-term low flow data \\
\hline 3 & $\delta^{18} \mathrm{O}$ & Low elevation & Beginning of the event \\
\hline 4 & $\delta^{18} \mathrm{O}$ & High elevation & Beginning of the event \\
\hline 5 & $\delta^{2} \mathrm{H}$ & Low elevation & Long-term low flow data \\
\hline 6 & $\delta^{2} \mathrm{H}$ & High elevation & Long-term low flow data \\
\hline 7 & $\delta^{2} \mathrm{H}$ & Low elevation & Beginning of the event \\
\hline 8 & $\delta^{2} \mathrm{H}$ & High elevation & Beginning of the event \\
\hline
\end{tabular}

\section{Results and discussion}

\subsection{Hydrometric data}

Summer is the season of maximum precipitation in the study area. Consequently, catchment runoff is higher in the summer months compared to mean annual values, although the number of rainfall-runoff events in particular years varies. Long-term discharge data from the Jalovecký Creek catchment showed that the study period was wetter than is typical for the end of June and July. Mean discharge in the study period 
was $1.13 \mathrm{~m}^{3} \mathrm{~s}^{-1}$ while the long-term average (1988-2016) for the same period was $0.94 \mathrm{~m}^{3} \mathrm{~s}^{-1}$. Five large rainfall-runoff events occurred during the study period (Fig. 2). Runoff in the headwater Škaredý Creek catchment was flashier than in the larger Jalovecký Creek catchment and individual rainfalls usually caused a more pronounced runoff response (e.g. during events 1 and 5). On the other hand, runoff event 3, which was quite large in the Jalovecký Creek catchment, was very small in the Škaredý Creek catchment. It should be noted, however, that rainfall during that event was smaller compared to other events, and smaller than rainfall during the same event in the Jalovecký Creek catchment.

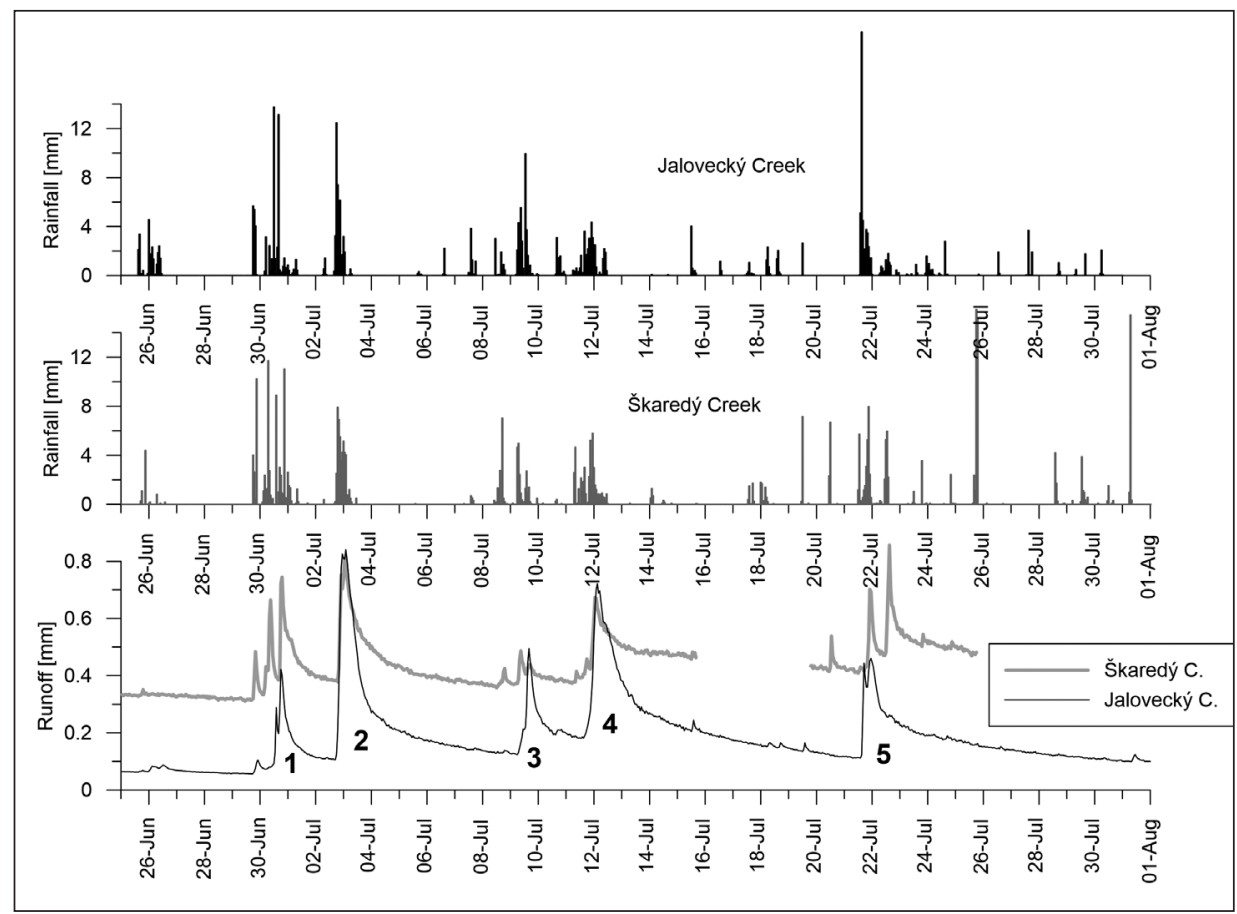

Figure 2. Hourly catchment precipitation and runoff in Jalovecký Creek and Škaredý Creek catchments; catchment precipitation was calculated by elevation gradients for catchment mean elevations; 11 gauges at elevations 820-1900 m a.s.l. were used for the Jalovecký Creek catchment, 2 gauges (1170 and 1778 m a.s.l.) were used for the Škaredy Creek catchment.

Basic characteristics of the rainfall-runoff events are given in Tables 2 and 3. Event water fraction was not separated for event 1 in the Škaredý Creek catchment because the isotopic composition of the stream before the event was not known. The data point to smaller catchment storage in the headwater Škaredý Creek catchment compared to that in the mesoscale Jalovecký Creek catchment. This is indicated by a flashier response at Škaredý Creek, and also by the fact that total event precipitation and runoff were almost the same for most events. However, the existence of delayed flow is visible in the hydrographs from both catchments. It is manifested in the discharge after the fast recession, which is notably higher than before the event, and it takes longer to return to the pre-event level. 
Table 2. Characteristics of rainfall-runoff events in the Jalovecky Creek catchment; event number corresponds to Fig. 2; $P, R, Q_{o}, Q_{\max }$ and CT are precipitation, runoff, discharge at the beginning of the event, peak discharge and time that elapsed between the beginning of rainfall and peak flow, respectively.

\begin{tabular}{|c|c|c|c|c|c|c|}
\hline Event & Duration & $\mathbf{P}[\mathbf{m m}]$ & $\mathbf{R}[\mathbf{m m}]$ & $\begin{array}{c}\mathbf{Q}_{\mathbf{o}} \\
{\left[\mathbf{m}^{3} \mathbf{s}^{-1}\right]}\end{array}$ & $\begin{array}{c}\mathbf{Q}_{\max } \\
{\left[\mathbf{m}^{3} \mathbf{s}^{-1}\right]}\end{array}$ & $\begin{array}{c}\mathbf{C T} \\
{[\mathbf{h o u r s}]}\end{array}$ \\
\hline 1 & $\begin{array}{c}6 / 29 / 201417: 00 \\
7 / 2 / 201417: 00(73 \text { hours })\end{array}$ & 62.8 & 10.2 & 0.346 & 2.6 & 25 \\
\hline 2 & $\begin{array}{c}7 / 2 / 201417: 00 \\
7 / 9 / 20146: 00(158 \text { hours) }\end{array}$ & 47.1 & 37.2 & 0.651 & 5.093 & 8 \\
\hline 3 & $\begin{array}{c}7 / 9 / 20146: 00 \\
7 / 11 / 201415: 00(58 \text { hours) }\end{array}$ & 51.6 & 13.2 & 0.762 & 3.050 & 12 \\
\hline 4 & $\begin{array}{c}7 / 11 / 201415: 00 \\
7 / 15 / 201412: 00(94 \text { hours) }\end{array}$ & 44.8 & 31.6 & 1.123 & 4.329 & 21 \\
\hline 5 & $\begin{array}{c}7 / 21 / 201414: 00 \\
7 / 26 / 201412: 00(121 \text { hours) }\end{array}$ & 64.5 & 25.7 & 0.691 & 2.836 & 10 \\
\hline
\end{tabular}

Table 3. Characteristics of rainfall-runoff events in the Škaredy Creek catchment; the symbols are the same as in Table 2.

\begin{tabular}{|c|c|c|c|c|c|c|}
\hline Event & Duration & $\mathbf{P}[\mathbf{m m}]$ & $\mathbf{R}[\mathbf{m m}]$ & $\begin{array}{c}\mathbf{Q}_{\mathbf{o}} \\
{\left[\mathbf{m}^{\mathbf{3}} \mathbf{s}^{-1}\right]}\end{array}$ & $\begin{array}{c}\mathbf{Q}_{\max } \\
{\left[\mathbf{m}^{3} \mathbf{s}^{-1}\right]}\end{array}$ & $\begin{array}{c}\mathbf{C T} \\
{[\text { hours }]}\end{array}$ \\
\hline 1 & $\begin{array}{c}6 / 29 / 201416: 00 \\
7 / 2 / 201417: 00(74 \text { hours) }\end{array}$ & 75.5 & 32.4 & 0.122 & 0.289 & 26 \\
\hline 2 & $\begin{array}{c}7 / 2 / 201419: 00 \\
7 / 8 / 201410: 00(136 \text { hours) }\end{array}$ & 50.0 & 60.8 & 0.147 & 0.379 & 11 \\
\hline 3 & $\begin{array}{c}7 / 9 / 20146: 00 \\
7 / 11 / 201405: 00(48 \text { hours) }\end{array}$ & 20.9 & 19.2 & 0.145 & 0.189 & 4 \\
\hline 4 & $\begin{array}{c}7 / 11 / 201408: 00 \\
7 / 15 / 201412: 00(101 \text { hours })\end{array}$ & 48.6 & 49.6 & 0.147 & 0.262 & 19 \\
\hline 5 & $\begin{array}{c}7 / 21 / 201412: 00 \\
7 / 25 / 201418: 00(103 \text { hours) }\end{array}$ & 54.1 & 53.5 & 0.159 & 0.333 & 28 \\
\hline
\end{tabular}

Correlation matrices based on data presented in Tables 2 and 3 did not lead to generalized conclusions about the rainfall-runoff relationships in the study catchments due to a small number of observed events. A positive correlation between rainfall amount and peak flow was indicated in the headwater catchment of Škaredý Creek. On the other hand, some unexpected relationships were found, e.g. a positive correlation between rainfall amount and time elapsed between the beginning of rainfall and peak discharge in Škaredý Creek or a negative correlation between rainfall amount and peak flow in Jalovecký Creek. 


\subsection{Isotopic composition of precipitation and runoff}

Summary information of the isotopic composition of precipitation and runoff for the entire study period is presented in Figure 3. The boxplots show a pronounced altitude gradient in the isotopic composition of precipitation in both catchments. Precipitation in the mountains, i.e. approximately above $1000 \mathrm{~m}$ a.s.l., clearly had higher deuterium excess than that in the lowlands. Stream water at the outlets of the catchments was isotopically very light, especially at Jalovecký Creek. This would mean either that streams deliver water from the highest altitudes, or more likely that snowmelt water was still an important part of catchment runoff in July 2014. The smaller ranges of $\delta^{18} \mathrm{O}$ and $\delta^{2} \mathrm{H}$ in the Škaredý Creek catchment indicate less snowmelt water influence than in the Jalovecký Creek catchment. This can result from the small catchment area, smaller storage capacity, and southern orientation of the Škaredý Creek catchment.

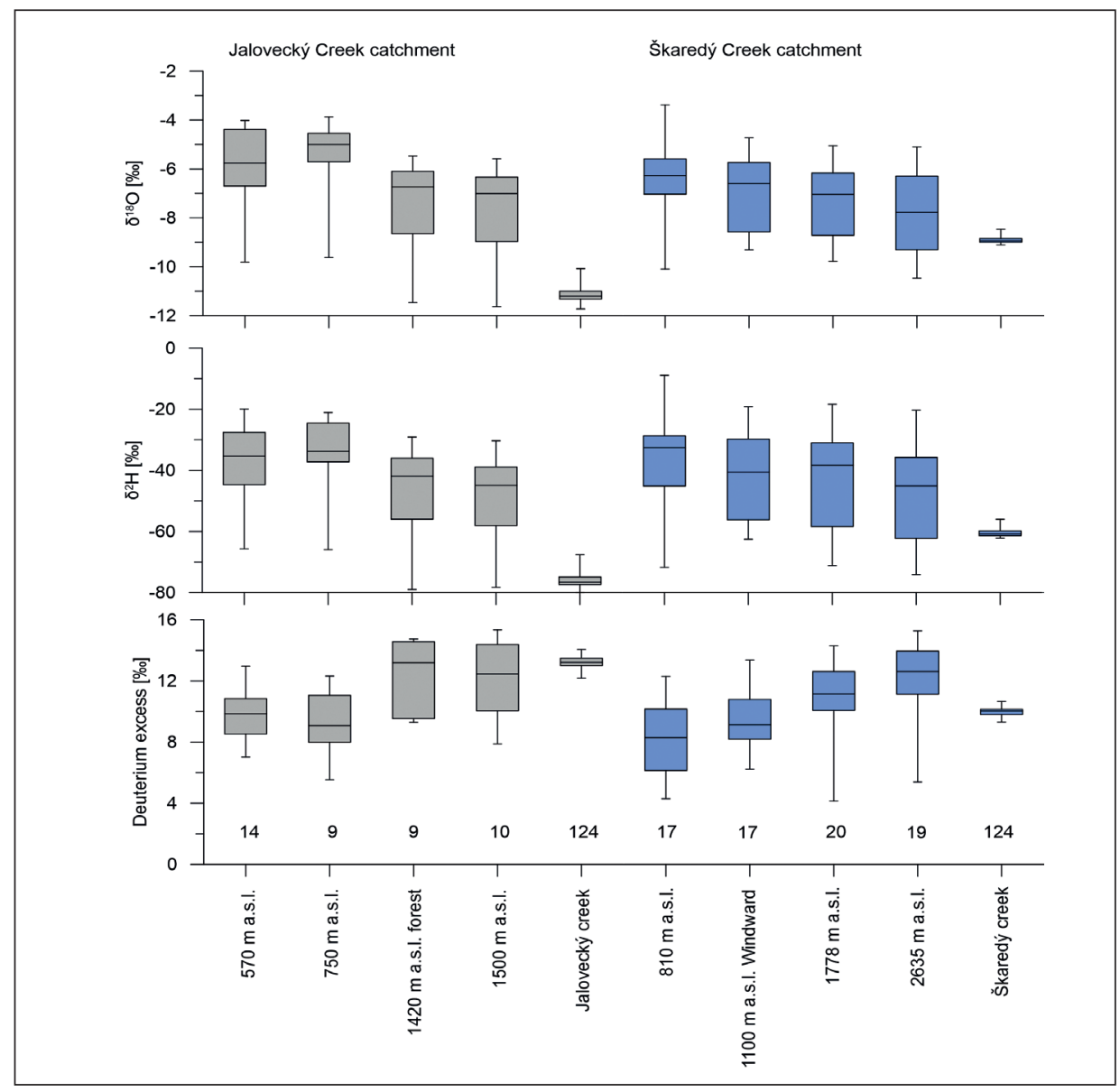

Figure 3. Isotopic composition of all precipitation and streamflow samples collected during the study period; the whiskers represent minima and maxima; numbers of samples are given below the graphs in the bottom panel. 
Elevational gradients of $\delta^{18} \mathrm{O}, \delta^{2} \mathrm{H}$ and deuterium excess calculated for the entire study period are $-0.18 \%$, $-1.1 \%$ and $0.29 \%$ per $100 \mathrm{~m}$, respectively (Fig. 4). Fig. 4 shows that gradients in the Western and High Tatra Mountains (the Jalovecký and Škaredý Creek catchments, respectively) are similar. Precipitation on the windward site of the High Tatra Mountains (at elevation 1100 m a.s.l. in Fig. 4) was isotopically much lighter than expected for its elevation. This site was therefore excluded in the calculation of elevation gradients (i.e. slopes of regression lines in Fig. 4) for $\delta^{18} \mathrm{O}$ and $\delta^{2} \mathrm{H}$. The slope and intercept of the regression line for deuterium excess were negligibly affected by including or excluding the value from the windward side gauge.

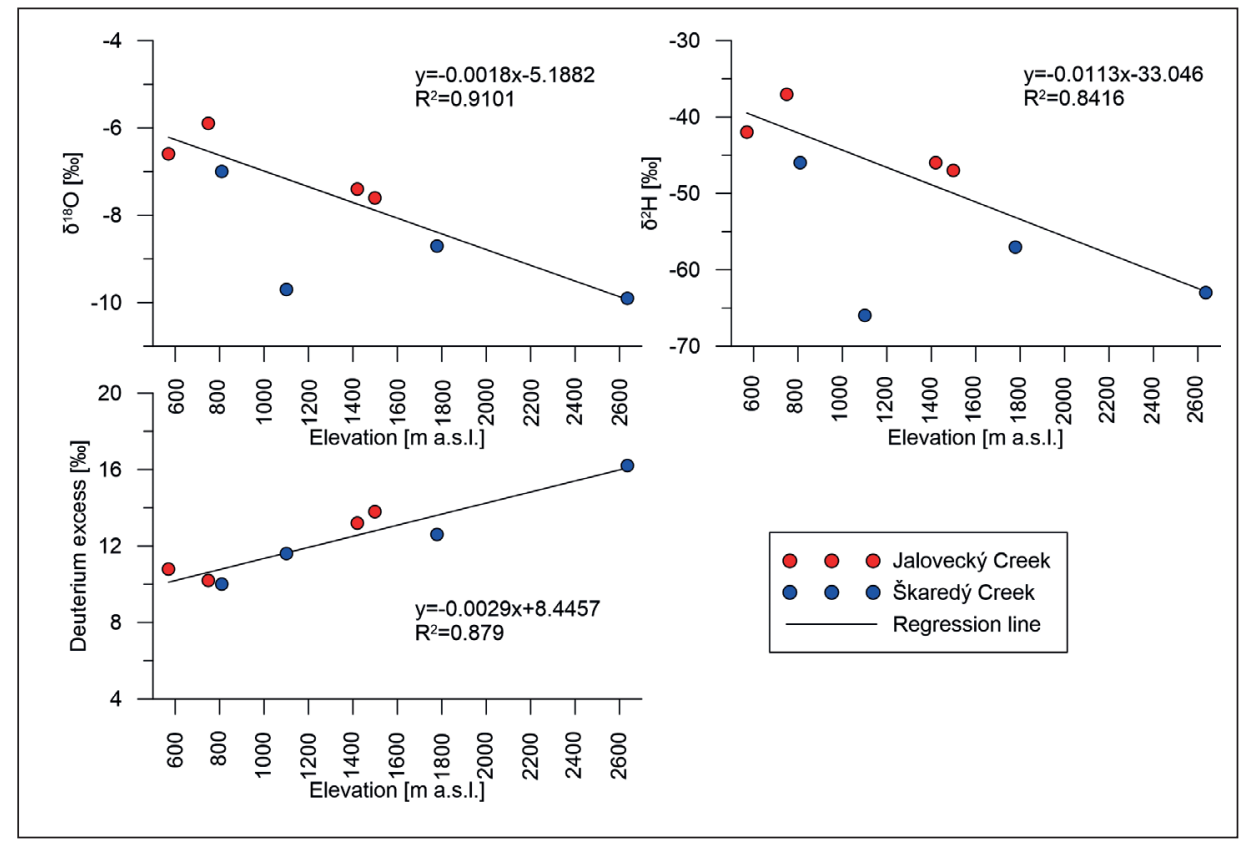

Figure $4 . \delta^{18} \mathrm{O}, \delta^{2} \mathrm{H}$ and deuterium excess in precipitation at different elevations in the Western Tatra Mountains (the Jalovecký Creek catchment) and in the High Tatra Mountains (the Škaredý Creek catchment); weighted averages over the study period.

Most rainfall was isotopically heavier than the stream water (Figs. 5 and 6). The Jalovecký Creek catchment showed a significant elevational gradient in precipitation between the catchment outlet and its mean elevation while the isotopic composition of precipitation at 750 and $570 \mathrm{~m}$ a.s.l. was mostly similar. Precipitation in the forest (1420 m a.s.1.) was isotopically heavier compared to the open area (1500 m a.s.1.), but the difference was relatively small. The range of temporal variability of isotopic composition of precipitation in the Jalovecký Creek catchment was about $8 \%$ for $\delta^{18} \mathrm{O}$ and $60 \%$ for $\delta^{2} \mathrm{H}$. The $\delta^{18} \mathrm{O}$ and $\delta^{2} \mathrm{H}$ values of stream water increased after the rainfalls by approximately $1.4 \%$ and $14 \%$, respectively. The isotopic composition of the creek at the end of July did not return to the lighter values observed at the end of June. Unpublished 
data from this catchment indicate that isotopically lighter water from snowmelt is present in the soil and catchment runoff at least until the end of June. Small rains between July 15 and 20 and after July 26 did not generate a significant runoff response and the variability of isotopic composition of Jalovecký Creek during that time was within the accuracy limits of isotopic analysis. More frequent sampling of the creek in such situations would therefore not provide additional information about runoff generation.

The range of temporal variability of isotopic composition of precipitation in the Škaredý Creek catchment was about $9 \%$ for $\delta^{18} \mathrm{O}$ and $70 \%$ for $\delta^{2} \mathrm{H}$. The maximum increase of stream water $\delta^{18} \mathrm{O}$ and $\delta^{2} \mathrm{H}$ after the rain storms was approximately $0.8 \%$ and $8 \%$, respectively.

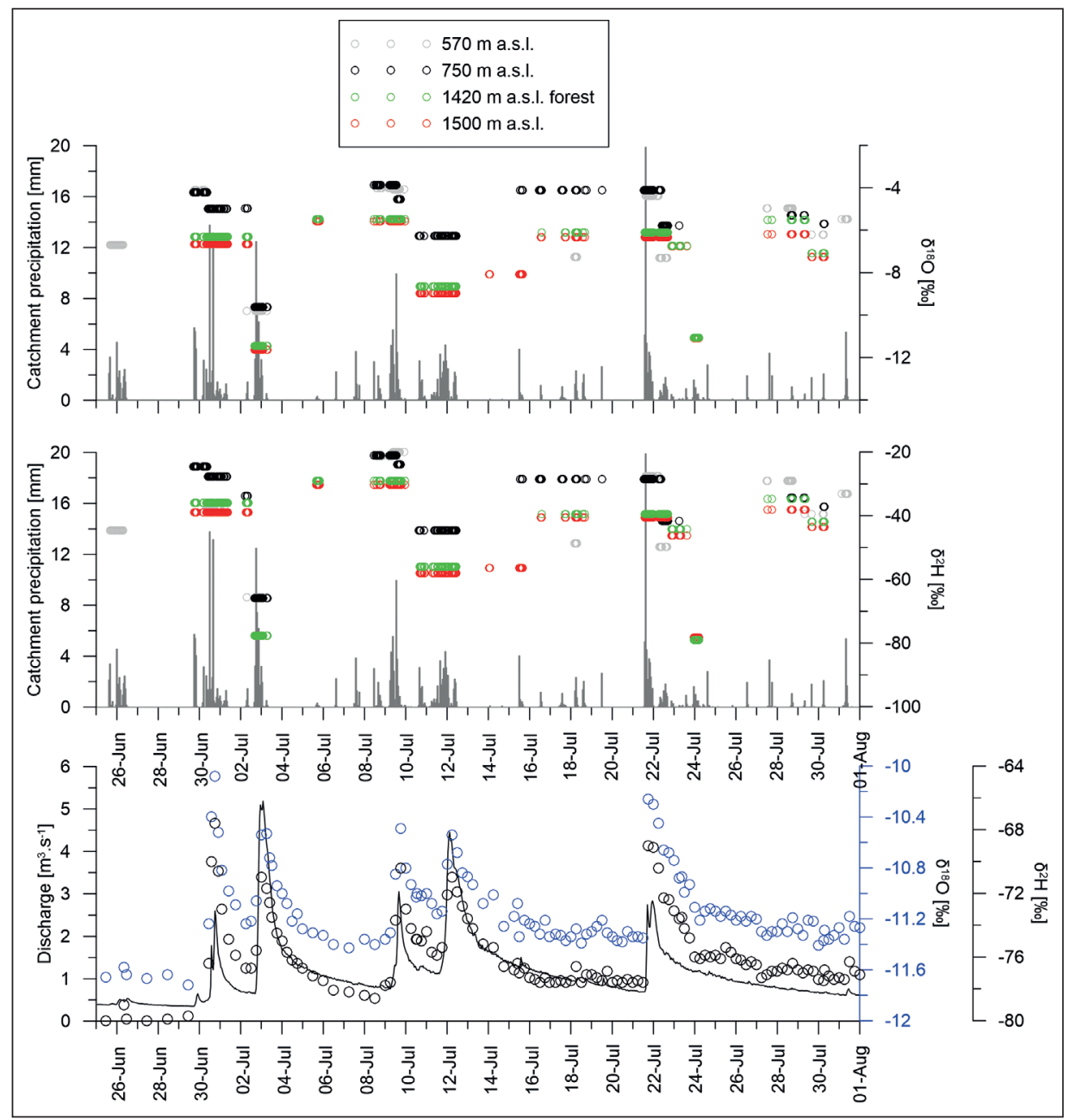

Figure 5. Hourly precipitation and discharge in the Jalovecky Creek catchment, isotopic composition of precipitation (sampled daily or after events) at different elevations and streamflow sampled at the catchment outlet. 


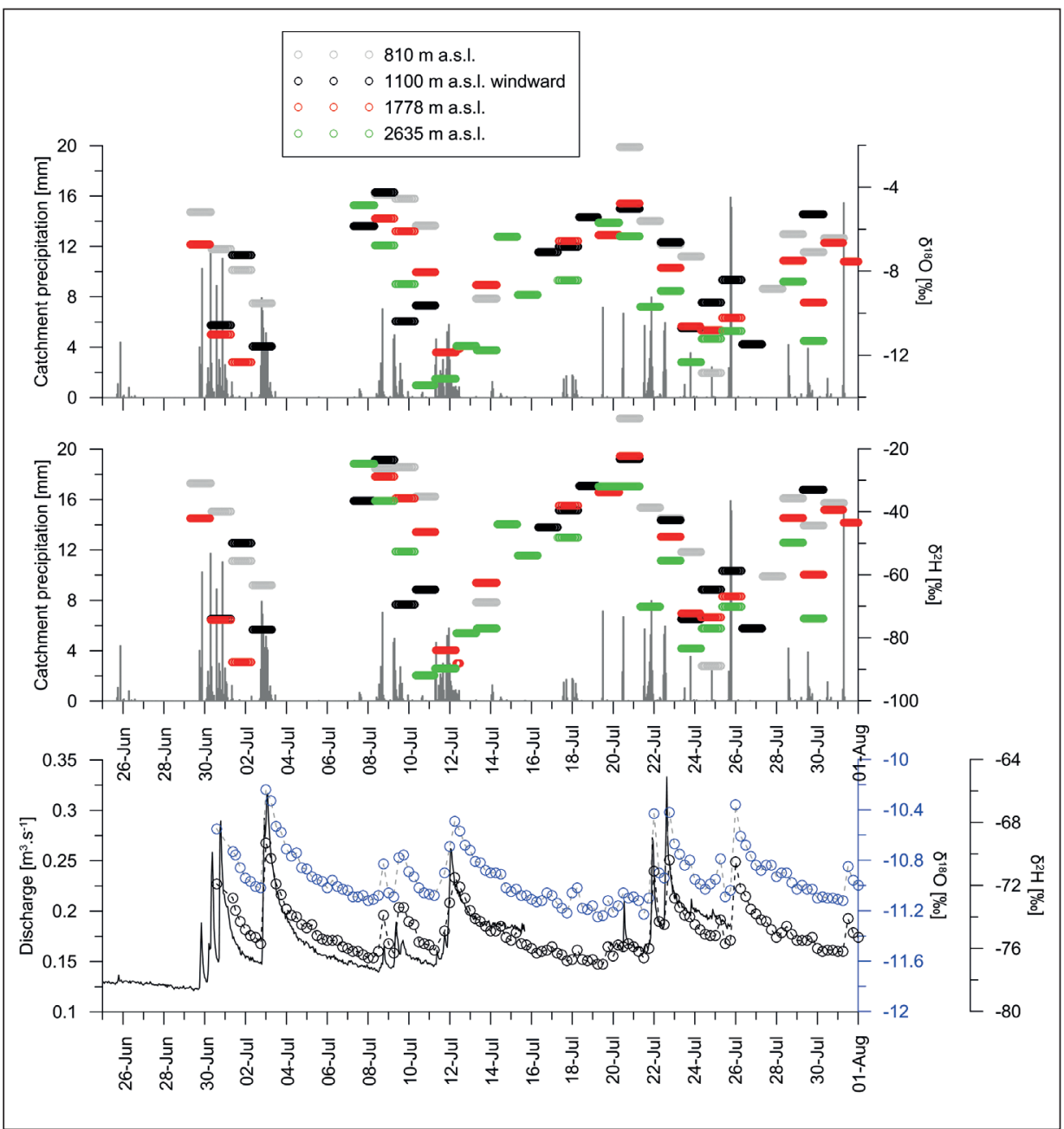

Figure 6. Hourly precipitation and discharge in the Škaredý Creek catchment, isotopic composition of daily precipitation at different elevations and streamflow sampled at the catchment outlet; rain gauge at $1100 \mathrm{~m}$ a.s.l. is on the windward (northern) side of the High Tatra Mountains; other rain gauges are on the lee side of the mountains shown in Figure 1.

\subsection{Isotopic hydrograph separation}

In total, the five events and eight combinations of end members described in the Methodology section yielded 40 values of event water fractions for the Jalovecký Creek catchment. In the Škaredý Creek catchment the number of values was 16 (4 events, 4 combinations). The results are summarized in Figure 7 and Table 4. 
Table 4. Event water fractions during peak flow; "E" stands for "event"; question mark indicates that the calculated event water fraction is not realistic (negative or greater than 1), Cv is coefficient of variation.

\begin{tabular}{|c|c|c|c|c|c|c|c|c|c|}
\hline \multirow{2}{*}{ Option } & \multicolumn{4}{|c|}{ Jalovecḱ́ Creek catchment } & \multicolumn{4}{c|}{ Škaredý Creek catchment } \\
\cline { 2 - 12 } & E1 & E2 & E3 & E4 & E5 & E2 & E3 & E4 & E5 \\
\hline 1 & 0.17 & 0.38 & 0.09 & 0.12 & 0.11 & & & & \\
\hline 2 & 0.23 & $?$ & 0.11 & 0.26 & 0.17 & & & & \\
\hline 3 & 0.24 & 0.43 & 0.13 & 0.13 & 0.15 & 0.52 & 0.05 & 0.11 & 0.18 \\
\hline 4 & 0.32 & $?$ & 0.15 & 0.28 & 0.21 & $?$ & 0.06 & $?$ & 0.24 \\
\hline 5 & 0.16 & 0.44 & 0.09 & 0.13 & 0.13 & & & & \\
\hline 6 & 0.20 & $?$ & 0.10 & 0.24 & 0.17 & & & & \\
\hline 7 & 0.23 & 0.63 & 0.14 & 0.16 & 0.17 & 0.53 & 0.06 & 0.11 & 0.18 \\
\hline 8 & 0.30 & $?$ & 0.16 & 0.28 & 0.23 & $?$ & 0.07 & $?$ & 0.22 \\
\hline Average & 0.23 & 0.47 & 0.12 & 0.20 & 0.17 & & 0.06 & & 0.21 \\
\hline Range & 0.16 & 0.25 & 0.07 & 0.16 & 0.12 & 0.01 & 0.02 & 0.00 & 0.06 \\
\hline Cv & 0.25 & 0.24 & 0.21 & 0.36 & 0.23 & & 0.14 & & 0.15 \\
\hline
\end{tabular}
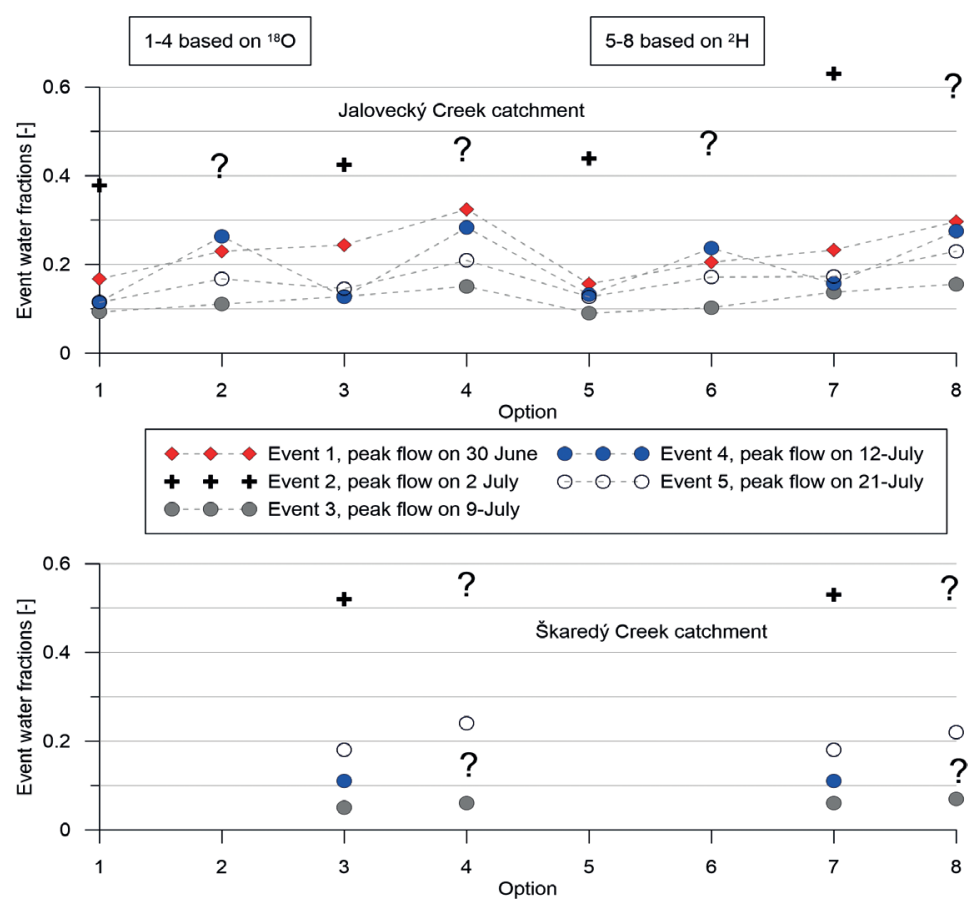

Figure 7. Event water fractions during peak flows in the Jalovecký Creek and Škaredý Creek catchments for different separation options described in Table 1; a question mark indicates that the calculated event water fraction was not realistic, i.e. either negative or greater than 1 (see discussion in the text). 
The results can be discussed from several points of view. One of them is the information on runoff generation they provided in the studied mountain catchments. From that point of view the IHS showed that peak flow event water fractions in both catchments were with one exception less than 0.3. Event water fractions were much higher during the peak flow of event 2 (about 0.47 in the Jalovecký Creek catchment and about 0.5 in the Škaredý Creek catchment). Event 2 was preceded by high precipitation before and during event 1 (about $100 \mathrm{~mm}$ in the Jalovecký Creek catchment), and began on the falling limb of event 1 . Intensive rainfall, especially in the Jalovecký Creek catchment (maximum intensity about $12 \mathrm{~mm} \mathrm{~h}^{-1}$ ) occurred during the event as well (Fig. 2). The smallest event water contributions (about 0.12 in the Jalovecký Creek catchment and about 0.06 in the Škaredý Creek catchment) occurred in event 3, which was preceded by longer period of runoff recession. The results indicate that event water fractions in the headwater Škaredný Creek catchment were similar to those in the meso-scale Jalovecký Creek catchment. However, it should be kept in mind that only a small number of events was available for comparison.

As commonly happens during isotopic hydrograph separation of events caused by rainfall, calculated event water fractions were sometimes negative or greater than 1 . This condition was caused by violating the constraint that $C_{t}$ must fall between $C_{p}$ and $C_{e}$. In the Jalovecký Creek catchment it happened four times during event 2 when the isotopic composition of precipitation from the high elevation was used as the new water component. In options 2,4 and 6 the high elevation rainfall $\left(C_{e}\right)$ was isotopically lighter than both total $\left(C_{t}\right)$ and pre-event $\left(C_{p}\right)$ components of equation 1. $C_{e}$ in option 8 was isotopically lighter than $C_{t}$ and heavier than $C_{p}$. In the Škaredý Creek catchment, the peak flow event water fractions were negative during events 2 (two times) and 4 (two times). In all these cases $C_{e}$ was represented by the isotopic composition of rainfall sampled at high elevation, which was isotopically lighter than both $C_{t}$ and $C_{p}$. End-members for all events are plotted together with the global and local meteoric water lines in Figure 8. The global meteoric water line $\left(\delta^{2} \mathrm{H}=8 \delta^{18} \mathrm{O}+10\right.$; Craig, 1961) is shown to allow comparison of our data with those from other studies. The local meteoric water line $\left(\delta^{2} \mathrm{H}=7.83 \delta^{18} \mathrm{O}+10.62\right)$, constructed for mountain precipitation (Holko et al., 2012b), differs only slightly from the global line. The position of samples with respect to the local meteoric water line shows that several precipitation samples in both catchments were evaporated, i.e. they plot below the meteoric water line (events 4 and 5 in the Jalovecký Creek catchment and event 5 in the Škaredý Creek catchment). Because precipitation amounts during those events were quite high for the given locations, we assume that evaporation did not occur in the rain gauge or during sample processing.

Another point of view of interpretation of the results is methodological. Unlike the case study specific point of view above, it has some more general consequences. Comparison of peak flow event water fractions calculated by different options for the end-member combinations shows that the differences are not negligible (Table 4). As shown by the coefficient of variation, the variability for each of the five events in the Jalovecký Creek catchment was greater than 20\%. The variability in the Škaredý Creek catchment was smaller (14 and 15\%), but there the amount of data was much smaller. Coefficients of variation were not calculated for less than 4 values. 


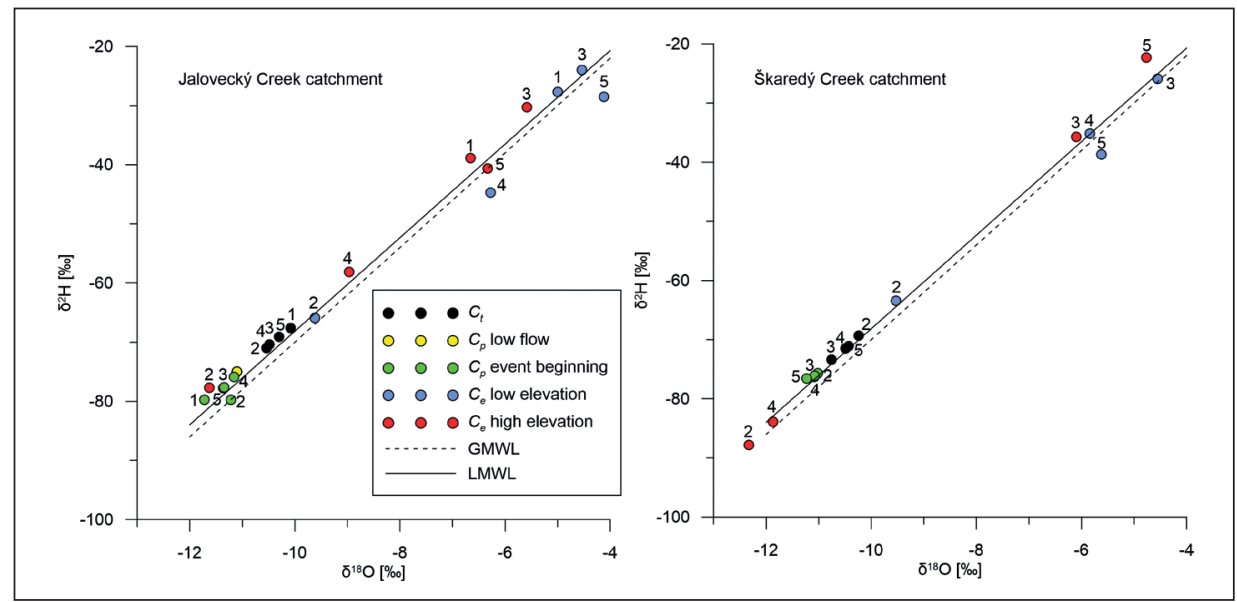

Figure 8. Differences in isotopic composition of end members for events 1-5; $C_{t}$ represents samples of streamflow collected at the outlets of the catchments, $C_{e}$ is isotopic composition of precipitation at two elevations, $C_{p}$ is either isotopic composition of streamflow at the beginning

of an event or the long-term isotopic composition of streamflow during low flow conditions; GMWL and LMWL are global and local meteoric water lines, respectively.

Meaningful comparison of the differences in peak flow event water fractions resulting from using $\delta^{18} \mathrm{O}$ vs. $\delta^{2} \mathrm{H}$ was possible only for the Jalovecký Creek catchment (except event 2). The mean values and coefficients of variation were mostly similar for both isotopes. The maximum difference was in event 4 , when the variability of the event water fraction with $\delta^{18} \mathrm{O}$ was higher $(\mathrm{Cv} 0.45)$ than with $\delta^{2} \mathrm{H}(\mathrm{Cv} 0.33)$.

\section{Conclusions}

Application of isotopic hydrograph separation for periods spanning several rainfallrunoff events is hampered mostly by difficulties related to precipitation sampling. While streamflow samples can be easily collected by automatic samplers, precipitation should be sampled at several locations, which may be difficult in larger and less accessible catchments, such as mountains. We presented isotopic data from streamflow and precipitation samples collected for approximately one month at relatively short time steps. The results confirmed high spatial and temporal variability of isotopic composition of precipitation, which causes methodological problems during isotopic hydrograph separations. The proposed approach of using the isotopic composition of precipitation from the low and high elevations as a range within which the "true" isotopic composition of catchment precipitation should vary, was not always successful. However, when it provided reasonable results, event water fractions calculated with isotopic signatures from the two "extreme" elevations differed usually by only 2-8\%. Calculated peak flow event water fractions in the two study mountain catchments were greater than $0.2-0.3$ only during one event which occurred under higher catchment wetness conditions. The low event water fractions suggest that large scale overland flow causing fast delivery 
of event water to the streams is not frequent in the study catchments. The number of rainfall-runoff events analysed was small, although considerable effort was invested to sample precipitation in the mountains on a daily/event basis. We did not have data to address the issue of changes in isotopic composition within individual rainfall events. However, our study shows that even if within-storm variation in isotopic composition is not taken into account, significant variability in results occurs by using various options for isotopic composition of precipitation and the pre-event component. It should be kept in mind that similar to other approaches used in hydrology (e.g. selection of parameters in hydrological modelling), several values for event and pre-event water contributions can be obtained from isotopic hydrograph separation. Thus, it is perhaps better to use a range of possible values instead of one "accurate number" to interpret IHS results.

\section{Acknowledgements}

The study was supported by research projects VEGA 2/0055/15 and APVV 150497. We would like to acknowledge financial support from the European Regional Development Fund Projects 26220120062 "Centre of excellence for the integrated river basin management in changing environmental conditions" and 26210120009 'Completion of infrastructure of hydrological research stations' which allowed purchase of the equipment. We are also grateful to Dr. J. Shanley for improving English.

\section{References}

Bičárová, S., Holko, L. 2013. Changes of characteristics of daily precipitation and runoff in the High Tatra Mountains, Slovakia over the last fifty years. Contributions to Geophysics and Geodesy 43 (2), 157-177. https://doi.org/10.2478/congeo-2013-0010.

Coplen, T.B., Wassenaar, L. 2015. LIMS for Lasers 2015 for achieving long-term accuracy and precision of $\delta 2 \mathrm{H}, \delta 17 \mathrm{O}$, and $\delta 18 \mathrm{O}$ of waters using laser absorption spectrometry. Rapid Commununications in Mass Spectrometry 29, 2122-2130. https://doi.org/10.1002/rcm.7372.

Craig, H. 1961. Isotopic variations in meteoric waters. Science 133, 1702-1703. https://doi. org/10.1126/science.133.3465.1702.

Dansgaard, W. 1964. Stable isotopes in precipitation. Tellus 16 (4), 436-468.

Dinçer, T., Payne, B., Florkowski, T., Martinec, J., Tongiorgi, E. 1970. Snowmelt runoff from measurements of tritium and oxygen-18. Water Resources Research 6 (1), 110-124. https:// doi.org/10.1029/WR006i001p00110.

Encyclopaedia Britannica. Carpathian Mountains. https://www.britannica.com/place/CarpathianMountains\#ref155912 (last acessed in June 2017).

Fleischer, P., Pichler, V., Fleischer P. Jr., Holko, L. Máliš, F., Gömöryová, E., Cudlín, P., Holeksa, J., Michalová, Z., Homolová, Z., Škvarenina, J., Střelcová, K., Hlaváč, P. 2017. Forest ecosystem services affected by natural disturbances, climate and land-use changes in the Tatra Mountains. Climate Research 73, 57-71. https://doi.org/10.3354/cr01461.

Froechlich, K., Kralik, M., Papesch, W., Rank, D., Scheifinger, H., Stichler, W. 2008. Deuterium excess in precipitation of Alpine regions - moisture recycling. Isotopes in Environmental and Health Studies 44 (1), 61-70. https://doi.org/10.1080/10256010801887208.

Genereux, D.P., Hooper, R.P. 1998. Oxygen and Hydrogen Isotopes in Rainfall-Runoff Studies. In: C. Kendall, J.J. McDonnell (Eds.), Isotope tracers in catchment hydrology, Elsevier, pp. 319-326. 
Hermann, A., Martinec, J., Stichler, W. 1978. Study of snowmelt-runoff components using isotope measurements. In: S.C. Colbeck, M. Ray (Eds.), Modeling of Snow Cover Runoff, U.S. Army Cold Regions Research and Engineering Laboratory, Hanover, New Hampshire, pp. 288-296.

Hlaváčiková, H., Novák. J., Holko, L. 2015. On the role of rock fragments and initial soil water content in the potential subsurface runoff formation. Journal of Hydrology and Hydromechanics 63 (1), 71-81. https://doi.org/10.1515/johh-2015-0002.

Holko, L. 1995. Stable environmental isotopes of ${ }^{18} \mathrm{O}$ and ${ }^{2} \mathrm{H}$ in hydrological research of mountainous catchment. Journal of Hydrology and Hydromechanics 43 (4-5), 249-274.

Holko, L. 2015. Syringe life and memory effects in isotopic analyses performed by liquid water isotopic analysers - a case study for natural waters from central Europe. Isotopes in Environmental and Health Studies 52, 553-559. https://doi.org/10.1080/10256016.2015.10 90987.

Holko, L., Kostka, Z. 2007. Snow cover in northern Slovakia - past, present and future. Folia Geographica Series Geographica-Physica 37-38 (1), 37-51.

Holko, L., Kostka, Z. 2008. Hydrological characteristics of snow cover in the Western Tatra Mountains in winters 1987-2008. Folia Geographica, Series Geographica-Physica 39, 6377.

Holko, L., Kostka, Z. 2010. Hydrological processes in mountains - knowledge gained in the Jalovecky Creek catchment, Slovakia. In: A. Herrmann, S. Schumann (Eds.), Status and Perspectives of Hydrology in Small Basins, IAHS Publications 336, pp. 84-89.

Holko, L., Škvarenina, J., Kostka, Z., Frič, M., Staroň, J. 2009a. Impact of spruce forest on rainfall interception and seasonal snow cover evolution in the Western Tatra Mountains, Slovakia. Biologia 64 (3), 594-599. https://doi.org/10.2478/s11756-009-0087-6.

Holko, L., Hlavatá, H., Kostka, Z., Novák, J. 2009b. Hydrological regimes of small catchments in the High Tatra Mountains before and after extraordinary wind-induced deforestation. Folia Geographica Series Geographica-Physica 40, 33-44.

Holko, L., Kostka, Z., Gorbachova, L. 2011a. Snow Hydrology in Central Europe. Geography Compass 5 (4), 200-218. https://doi.org/10.1111/j.1749-8198.2011.00412.x.

Holko, L., Kostka, Z., Šanda, M. 2011b. Assessment of frequency and areal extent of overland flow generation in a forested mountain catchment. Soil \& Water Research 6 (1), 43-53. https://doi. org/10.17221/33/2010-SWR

Holko, L., Fleischer, P., Novák, V., Kostka, Z., Bičárová, S., Novák, J. 2012a. Hydrological effects of a large scale windfall degradation in the High Tatra Mountains, Slovakia. In: J. Krecek, M.J. Haigh, T. Hofer, E. Kubin (Eds.), Management of Mountain Watersheds, Springer, pp. 164-179.

Holko, L., Dóša, M., Michalko, J., Kostka, Z., Šanda, M. 2012b. Isotopes of oxygen-18 and deuterium in precipitation in Slovakia. Journal of Hydrology and Hydromechanics 60 (4), 265-276. https://doi.org/10.2478/v10098-012-0023-2.

Holko, L., Danko, M., Dóša, M., Kostka, Z., Šanda, M., Pfister, L., Iffly, J.F. 2013. Spatial and temporal variability of stable water isotopes in snow related hydrological processes. Die Bodenkultur 64 (3-4), 39-45.

Klaus, J., McDonnell, J.J. 2013. Hydrograph separation using stable isotopes: Review and evaluation. Journal of Hydrology 505, 47-64. https://doi.org/10.1016/j.jhydrol.2013.09.006.

Kostka, Z. 2009. Runoff response to rainfall event in the mountain catchment. Acta Hydrologica Slovaca 10 (1), 113-122.

Kostka, Z., Holko, L. 2003. Analysis of rainfall-runoff events in a mountain catchment. In: L. Holko, P. Miklánek (Eds.), Interdisciplinary approaches in small catchment hydrology: Monitoring and research. Technical Documents in Hydrology, No. 67, UNESCO, Paris, pp. 19-25. 
Kostka, Z., Holko, L. 2007. Effect of landuse change on hydrological regime in the upper Váh river catchment. Meteorologický Časopis 10, 193-197.

Krajčí, P., Danko, M., Hlavčo, J., Kostka, Z., Holko, L. 2016. Experimental measurements for improved understanding and simulation of snowmelt events in the Western Tatra Mountains. Journal of Hydroly and Hydromechanics 64 (4), 316-328. https://doi.org/10.1515/johh-20160038 .

Lyon, S.W., Desilets, S.L.E., Troch, P.A. 2009. A tale of two isotopes: differences in hydrograph separation for a runoff event when using $\delta \mathrm{D}$ versus $\delta^{18} \mathrm{O}$. Hydrological Processes 23, 2095 2101. https://doi.org/10.1002/hyp.7326.

Merlivat, L., Jouzel, J. 1979. Global climatic interpretation of the deuterium-oxygen 18 relationship for precipitation. Journal of Geophysical Research 84, 5029-5033. https://doi.org/10.1029/ JC084iC08p05029.

Mook, W., Groeneveld, D., Brown, A., Van Ganswijk, A. 1974. Analysis of a runoff hydrograph by means of natural ${ }^{18} \mathrm{O}$. In: Isotope Techniques in Groundwater Hydrology. International Atomic Energy Agency, Vienna, pp. 145-156.

Oshun, J., Dietrich, W.E., Dawson, T.E., Fung, I. 2016. Dynamic, structured heterogeneity of water isotopes inside hillslopes. Water Resources Research 52, 164-189. https://doi. org/10.1002/2015SWR017485.

Parajka, J., Holko, L., Kostka, Z., Blöschl, G. 2012. MODIS snow cover mapping accuracy in a small mountain catchment - comparison between open and forest sites. Hydrology and Earth System Sciences 16, 2365-2377. https://doi.org/10.5194/hess-16-2365-2012.

Pfahl, S., Sodemann, H. 2014. What controls deuterium excess in global precipitation? Climate of the Past 10, 771-781. https://doi.org/10.5194/cp-10-771-2014.

Pinder, G.F., Jones, J.F. 1969. Determination of the ground-water component of peak discharge from the chemistry of total runoff. Water Resources Research 5 (2), 438-445. https://doi. org/10.1029/WR005i002p00438.

Rodhe, A. 1998. Snowmelt-Dominated Systems. In: C. Kendall, J. J. McDonnell (Eds.), Isotope tracers in catchment hydrology, Elsevier, pp. 391-433.

Sklash, M.G., Farvolden, R.N. 1979. The role of groundwater in storm runoff. Journal of Hydrology 43 (1-4), 45-65. https://doi.org/10.1016/0022-1694(79)90164-1.

Wassenaar, L.I., Coplen, T.B., Aggarwal, P.K. 2013. Approaches for achieving long-term accuracy and precision of $\delta^{18} \mathrm{O}$ and $\delta^{2} \mathrm{H}$ for waters analysed using laser absorption spectrometers. Environmental Science and Technology 48, 1123-1131. https://doi.org/10.1021/es403354n. 